
INCLUSÃO ESCOLAR - UAB/UnB

\title{
INCLUSÃO ESCOLAR DE ALUNOS EM SITUAÇÃO DE RISCO SOCIAL: DESAFIOS E POSSIBILIDADES
}

\author{
CASSIA GUIDONI
}

ORIENTADORA: Profa. Ma. Alia Maria Barrios González 
Monografia apresentada ao Curso de Especialização em Desenvolvimento Humano, Educação e Inclusão, da Faculdade UAB/UnB Pólo de Vitória. Orientadora: Professora Ma. Alia Maria Barrios González 


\title{
TERMO DE APROVAÇÃO
}

\author{
CASSIA GUIDONI
}

\section{INCLUSÃO ESCOLAR DE ALUNOS EM SITUAÇÃO DE RISCO SOCIAL: DESAFIOS E POSSIBILIDADES}

Monografia aprovada como requisito parcial para obtenção do grau de Especialista do Curso de Especialização em Desenvolvimento Humano, Educação e Inclusão Escolar - UAB/UnB. Apresentada em / 2011.

Aprovada pela banca formada pelos professores:

Profa. Ma. Alia Maria Barrios González (Orientadora)

Profa. Dra. Mercedes Villa Cuplillo (Examinadora)

Cassia Guidoni (Cursista)

BRASÍLIA/2011 


\section{DEDICATÓRIA}

Dedico essa pesquisa aos meus alunos que sempre me motivaram a buscar alternativas para melhor entendê-los e atendê-los. 


\section{AGRADECIMENTOS}

Aos meus filhos que me acompanharam durante o curso. Arthur que me ajudou no uso de alguns equipamentos, e ouviu minhas leituras, Bernardo que conseguiu ficar de boca fechada, tarefa praticamente impossível, durante a transcrição das entrevistas.

Às minhas irmãs que me apoiaram e ouviram, contribuíram com colocações e sugestões.

Aos colegas que colaboraram com as suas colocações e aceitaram participar dessa pesquisa.

Às coordenadoras da escola que me ajudaram a "laçar" os colegas flexibilizando os horários para que as entrevistas acontecessem.

A toda a equipe da escola que, mesmo não fazendo parte direta desse estudo, contribuiu para que acontecesse com discussões aprofundadas sobre a questão e me motivou a fazê-lo.

À Alia, pela gentileza e forma agradável de orientar, durante toda a jornada deste curso.

À dois alunos em especial, que em 2009 deixaram meu coração apertado, e me motivaram e desafiaram a pensar novas possibilidades de atendê-los e assim buscar alternativas junto com a equipe pedagógica motivando a escola alternativas mais inclusivas. 


\section{RESUMO}

Crianças com grande dificuldade para se adequar ao ambiente escolar, que não se apropriam do mínimo conhecimento oferecido pela escola, com grande dificuldade de manter a concentração em sala de aula, passam vários anos em uma mesma série, vivem em situação de vulnerabilidade social. As dificuldades e a incapacidade de se adaptar ao ambiente escolar aumentam a vulnerabilidade da criança. Essas questões desafiam a escola a buscar alternativas e projetos que viabilizem a inclusão ao ambiente e aos conteúdos escolares. Professores sem formação adequada são desafiados cotidianamente a buscar alternativas que incluam essas crianças no contexto escolar e da sala de aula, mas nem sempre conseguem. A inclusão vinda de cima para baixo faz com que o professor inclua sem ter a formação adequada para isso. $\mathrm{O}$ histórico de exclusão social faz com que as famílias não acompanhem a vida escolar dos seus filhos. Todos esses fatores sobrecarregam a escola com situações que estão além de sua resolução. A falta de políticas públicas que juntamente com a escola e a família minimizem essas questões e possibilitem a real inclusão da criança no contexto escolar e da sala de aula, viabilizando a aquisição de conhecimento que é o objetivo principal ao frequentar uma escola. Este trabalho procurou estudar os desafios e as possibilidades de inclusão escolar dos alunos em situação de risco social e dificuldade de aprendizagem. Foram realizadas entrevistas com os profissionais da escola, onde ficou ressaltada a necessidade urgente de formação em inclusão escolar, e com isso possibilitar o desenvolvimento cultural e social desses alunos, respeitando suas diferenças e atendendo as suas necessidades.

Palavras-chaves: inclusão, formação profissional, risco social, exclusão social, dificuldade de aprendizagem, adaptação ao ambiente escolar. 


\section{SUMÁRIO}

RESUMO

APRESENTAÇÃO

I - FUNDAMENTAÇÃO TEÓRICA

II - OBJETIVOS

III - METODOLOGIA

3.1 - Fundamentação Teórica da Metodologia

3.2 - Contexto da Pesquisa

3.3 - Participantes

3.4 - Materiais

3.5 - Procedimentos de Construção de Dados

3.6 - Procedimentos de Análise de Dados

IV - RESULTADOS E DISCUSSÕES

4.1 - Análise das Entrevistas

V - CONSIDERAÇÕES FINAIS

REFERÊNCIAS

APÊNDICES

ANEXOS 


\section{APRESENTAÇÃo}

Em 1999, concluí o Curso de Educação Artística na Universidade Federal do Espírito Santo. Iniciei minha carreira profissional em oficinas para menores em risco social, promovidos por várias entidades de assistência, onde eram oferecidos vários cursos, dentre eles cursos de mosaico e de reciclagem em jornal, com os quais trabalhei. Eram jovens em liberdade assistida, que precisavam passar por esses cursos como uma forma de ressocialização e a possibilidade de resgate da autoestima por intermédio das oficinas de arte. Para dar aulas nesses cursos, foram escolhidos profissionais que se identificassem com o público alvo, e a partir da identificação dos profissionais, passamos por uma formação de duas semanas com estudos e dinâmicas para lidar com possíveis situações de estresse e como sair delas. Formação esta necessária para que os profissionais envolvidos não perdessem o foco do conteúdo, durante o curso.

Em 2002, iniciei minha atuação como professora no ensino regular em um grande escola estadual de ensino médio, onde trabalhei até 2003. Ainda em 2003, comecei a dar aulas de arte em uma escola particular no município de Vila Velha, dando aulas para todas as turmas do Ensino Fundamental, de $1^{\mathrm{a}}$ a $8^{\mathrm{a}}$ séries. Essa escola foi muito importante na minha formação profissional, pois até então eu não tinha experiência com crianças, e não sabia nem como me dirigir a elas. Lá aprendi muito e assim fui elaborando meu planejamento de forma articulada e progressiva. No ano de 2005, fui chamada para assumir uma cadeira de Ensino Fundamental na Prefeitura Municipal de Vitória, escolhi o turno matutino e continuei à tarde na escola particular. Em 2007, fiz outro concurso na Prefeitura Municipal de Vitória, buscando maior estabilidade profissional. Assumi essa nova cadeira em 2008, como Dinamizadora de Arte na educação infantil, na mesma região que já estava pela manhã. Assim vou conhecendo o perfil da comunidade que atuo, da educação infantil ao fim do ensino fundamental, onde conheço muitas famílias. Pelo fato de dar aulas para vários irmãos, vou percebendo as dificuldades na vida escolar da criança. Ao longo do tempo essas dificuldades são resolvidas, ou não, dentro das unidades escolares.

A minha atuação como professora de arte me proporciona um diálogo diferente com meus alunos, e percebo que muitos não conseguem parar para executar uma atividade, por mais 
simples que seja, participam da minha aula, mas não conseguem se concentrar a ponto da criatividade fluir, frequentam a mesma série por mais de um ano, apresentam dificuldades de leitura, muitas vezes seu comportamento os leva a sucessivas suspensões. A atitude da escola, em muitos momentos, não proporciona a inclusão dos alunos em risco social, a falta de formação em educação inclusiva dos professores e o grande número de alunos em sala de aula, não ajudam o professor a ter um olhar diferenciado. A política de "inclusão" destes alunos acaba sendo a progressão, o avanço dele de uma série para outra, mas sem se preocupar com a inclusão dele no processo de construção do conhecimento, simplesmente avançar para que ele saia da escola.

\footnotetext{
A cadeia de eventos que conduz muitos adolescentes para grupos anti-sociais começa no lar, durante a meninice; os elos nessa cadeia incluem práticas educativas coercitivas e punitivas, que contribuem para o desenvolvimento de agressão e fracasso escolar; (Trivellato Ferreira e Marturano, 2002)
}

A escola não consegue lidar com eles, vivem sempre suspensos, ficam mais fora da escola do que dentro dela, apesar de estarem matriculados e fazerem parte das estatísticas de alunos frequentes, chegam, em sua maioria, ao fim do ensino fundamental mal sabendo ler, e não compreendendo e interpretando o que leem.

O objetivo dessa pesquisa é fazer um levantamento dos desafios que o processo de inclusão dos alunos em risco social coloca para o contexto escolar e para os profissionais da educação. Buscar junto com o grupo de professores que atuam com essa realidade, mecanismos para melhor atendê-los, minimizando o número de suspensões e incluindo-os no processo de aquisição de conhecimento.

A partir dos resultados do estudo, esperamos tecer considerações, para mudar um pouco o olhar do professor que atua com alunos em situação de risco social, tentando não resolver as questões sociais que atrapalham o seu rendimento, mas entender suas dificuldades e ajudar a superá-las. O entendimento e a aceitação do fato faz com que nos tornemos mais humanos e acessíveis a essas crianças tornando a relação mais saudável e consequentemente conseguindo cumprir melhor a nossa função de professores. 


\section{FUNDAMENTAÇÃO TEÓRICA}

As mudanças na estrutura familiar, com famílias, cada vez mais, sendo chefiadas por mulheres, que ficam distantes de casa o dia todo e ganham baixos salários, faz com que nossas crianças fiquem cada vez mais sozinhas ou sejam criadas por parentes, já que os pais precisam trabalhar para manter a casa, com uma renda precária, normalmente têm subempregos. As mães, em sua maioria, trabalham como diaristas ou empregadas domésticas. Muitas, ainda, deixam os filhos com a mãe e partem para outros relacionamentos. Os programas sociais que existem para tirar essas crianças do risco social, recebem-nas, preenchem-lhes o tempo com atividades extras, mas isso não é suficiente para que essas crianças se sintam amparadas, e os apelos do tráfico, muitas vezes, falam mais alto, pois o “amparo" que tanto anseiam é ali oferecido.

Da pobreza ao risco, há um olhar que de antemão e arbitrariamente exclui "o menor"da sociedade, como se ele não fizesse parte dessa, mas poderá quem sabe um dia fazê-lo, caso adapte-se às prescrições que lhe forem impostas. Ao excluir não apenas retiramos, ainda que ilusoriamente, o problema da "nossa sociedade", do "nosso mundo", mas nos isentamos de toda e qualquer responsabilidade - o risco está e fica restrito ao mundo do outro, aos que vivem "em um outro mundo". Iludimo-nos acreditando que se o "menor" estivesse inserido na "nossa" sociedade, talvez não fosse de risco, porque a vemos como boa e acolhedora e depositamos a "culpa" pelo "desvio" na pessoa e no meio familiar: (Hüning e Guareschi, 2002)

A escola não se adaptou a essa realidade, e até o presente momento não cria mecanismos para realmente incluir esses alunos na sua realidade, ela quer que os alunos "tomem consciência" de que precisam se adequar ao meio, expressão essa ouvida recorrentemente nos corredores e nas sala de professores. Essa realidade é antiga e até hoje não foram foram pensadas estratégias para evitar esse tipo de situação.

\footnotetext{
“No fim do século XIX, (...) os juristas brasileiros descobrem o 'menor' nas crianças e adolescentes pobres das cidades, que por não estarem sob a autoridade de seus pais e tutores são chamadas por eles de abandonadas" (Londoño, 1991, p.135). Essa "descoberta" fez com que o Estado se voltasse à produção de técnicas, políticas e instituições direcionadas ao enfrentamento da "questão do menor". A partir de então, duas preocupações passaram a ganhar importância em relação aos "menores": a de buscar soluções em termos de assistência às crianças e adolescentes sem amparo material e moral; e a preocupação com a crescente criminalidade infantil e juvenil que, por sua vez, colocavam em risco a ordem da sociedade (Frontana, 1999), (Hüning e Guareschi, 2002)
}

Devemos ressaltar que a responsabilidade com o adolescente é também da escola e a forma de melhor lidar com ele deve ser pensada na escola com todos os seus profissionais. Ser 
professor de escola pública é resguardar ao adolescente seu direito ao conhecimento e buscar estratégias de ensino que incluam esse aluno no processo de aquisição de conhecimento.

Embora o Estatuto da Criança e Adolescente não defina diretamente as situações de risco pessoal e social, estas são entendidas pela negligência, exploração, violência, crueldade e opressão em relação à criança ou ao adolescente, promovendo um deslocamento da situação de irregularidade da criança para outras instâncias da sociedade, seja família, escola, Estado... (Hüning e Guareschi, 2002)

Claro que esta função não é somente da escola, mas ela precisa cumprir a sua parte que é a de garantir ao aluno pelo menos que ele saia do ensino fundamental apto a participar da vida da sociedade, que possa seguir em frente sem que seja prejudicado. A família precisa de alguma forma participar do processo educacional da criança.

\begin{abstract}
A escola e a família compartilham funções sociais, políticas e educacionais, na medida em que contribuem e influenciam a formação do cidadão (Rego, 2003). Ambas são responsáveis pela transmissão e construção do conhecimento culturalmente organizado, modificando as formas de funcionamento psicológico, de acordo com as expectativas de cada ambiente. Portanto, a família e a escola emergem como duas instituições fundamentais para desencadear os processos evolutivos das pessoas, atuando como propulsoras ou inibidoras do seu crescimento físico, intelectual, emocional e social. Na escola, os conteúdos curriculares asseguram a instrução e apreensão de conhecimentos, havendo uma preocupação central com o processo ensino-aprendizagem. Já, na família, os objetivos, conteúdos e métodos se diferenciam, fomentando o processo de socialização, a proteção, as condições básicas de sobrevivência e o desenvolvimento de seus membros no plano social, cognitivo e afetivo. (Dessem, Polonia - 2007)
\end{abstract}

Os projetos sociais precisam dar apoio à escola, serem parceiros. A escola não pode deixar de lado seu papel principal para ter uma postura assistencialista, precisa atender, formar, incluir o aluno no processo de aquisição do conhecimento. Ter professores preparados para lidar com o problema, ter um ambiente saudável que favoreça o estudo, faz parte do papel da escola. A escola muitas vezes "promove" esse aluno, ano a ano, sem garantir o mínimo de aprendizado, dessa forma não está cumprindo a sua parte. "O professor tem um papel mediador; um elo entre o conhecimento e o aluno.” (Dessem e Polonia, 2007). A escola não está preparada para lidar com toda essa diversidade de problemas.

É fato constatado que o nosso sistema regular de ensino, programado para atender àquele aluno "ideal", com bom desenvolvimento psico linguístico, motivado, sem problemas intrínsecos de aprendizagem, e oriundo de um ambiente sócio-familiar que lhe proporciona estimulação adequada, tem se mostrado incapaz de lidar com o número cada vez maior de alunos que, devido a problemas sociais, culturais, psicológicos e/ou de aprendizagem, fracassam na escola. (Glat, Nogueira, 2002)

Acredito que fracassar não seria o termo apropriado para ilustrar a situação desses alunos na escola, para eles a escola não é prioridade e com isso não se dedicam a ela da forma como 
deveriam. Cabe à escola e a toda sua equipe buscar alternativas para envolver esses alunos no processo de ensino e levá-los a se dedicar e valorizar os estudos como forma de mudança de vida, para eles e para a própria família. A motivação para os estudos nesses casos parte somente da escola, visto que a família está inserida em um contexto de exclusão social a um longo tempo, não tem como prioridade a formação escolar dos seus filhos. Sem apoio familiar, espaço adequado para os estudos em casa, a criança não vai prolongar em casa o que viu na escola, o momento de estudo doméstico tão importante na sua formação escolar não acontece por falta dessa infraestrutura adequada. Uma escola estruturada e preparada para lidar com esse perfil de alunos vai estudar melhores alternativas para dentro do seu horário, tornar as aulas mais participativas e interativas, despertando o interesse dos alunos a buscar mais e vencer assim suas dificuldades.

Métodos psicopedagógicos, estratégias e técnicas de estimulação que minimizem as deficiências cognitivas ocasionadas pelas condições adversas, devem ser encontradas para possibilitar às crianças oportunidade de aprendizagem escolar satisfatória e inclusão social. (Macedo, Andreucci, Montelli, 2004)

Entender que a dificuldade está além da esfera da escola, e que a realidade do aluno chega para a escola como um fator dificultador da sua ação, é importante para que todos os profissionais possam buscar alternativas para melhorar o atendimento das demandas, buscando parcerias e desenvolvendo projetos para minimizar os problemas dentro da escola. Para isso é preciso investir na formação dos profissionais da educação, preparando-os para lidar com essa diversidade de problemas de forma clara e eficiente, sabendo o que os espera, consciente das dificuldades que irá enfrentar e buscar alternativas tornar sua atuação eficiente.

\footnotetext{
É preciso preparar todos os professores, com urgência, para se obter sucesso na inclusão, através de um processo de inserção progressiva; assim eles poderão aceitar e relacionar-se com seus diferentes alunos e, consequentemente, com suas diferenças e necessidades individuais. Porém, os professores só poderão adotar este comportamento se forem convenientemente equipados com recursos pedagógicos, se a sua formação for melhorada, se lhes forem dados meios de avaliar seus alunos e elaborar objetivos específicos, se estiverem instrumentados para analisar a eficiência dos programas pedagógicos, preparados para a superação dos medos e superstições e contarem com uma orientação eficiente nesta mudança de postura para buscar novas aquisições e competências. (Glat, Nogueira, 2002)
}

O professor, nos seus cursos de licenciatura, não aprende como lidar com os alunos, mas sim "coleciona" uma série de conteúdos que precisa passar e como trabalhador da educação "se coloca numa posição de funcionário, de trabalhador da escola, numa condição de assalariado que tem que trabalhar muito."(professor E)

O professor, agindo de acordo com a formação recebida, costuma privilegiar certos 
conteúdos em detrimento de outros. Dessa forma, o saber pode se apresentar num circuito repetitivo e desvinculado da realidade do aluno o que faz com que o sujeito, continuamente, mantenha a mesma prática alienada. É o que tem acontecido com a maior parte dos nossos professores, sejam eles "regulares" ou "especiais". No entanto, é importante ressaltar que eles agem desta forma por não terem recebido, em seus cursos de formação e capacitação, suficiente instrumentalização que lhes possibilite estruturar a sua própria prática pedagógica para atender às distintas formas de aprendizagem de seu alunado. [...] A educação inclusiva, apesar de encontrar, ainda, sérias resistências (legítimas ou preconceituosas) por parte de muitos educadores, constitui, sem dúvida, uma proposta que busca resgatar valores sociais fundamentais, condizentes com a igualdade de direitos e de oportunidades para todos. Glat, Nogueira, 2002)

Os cursos de licenciatura deveriam formar professores inclusivos, prepará-los para as turmas que irão encontrar nas escolas, hoje os professores saem de seus cursos com uma série de conteúdos que precisam passar para uma turma "ideal", com alunos "ideais", e quando chegam nas escolas se deparam com turmas heterogêneas, alunos com necessidades educativas especiais (NEE) e também com alunos em situação de dificuldade de aprendizagem e excluídos socialmente e não sabem o que fazer, pois o que o sistema espera é que ele seja "mágico" e consiga dar suas aulas de forma tranquila e eficiente. Nada disso acontece, o professor precisa de uma formação adequada em seus cursos de licenciatura para chegar na escola melhor preparado, e os que já estão nas escolas precisam de formação em inclusão, urgentemente, mas se esbarra na falta de tempo do profissional, que em sua maioria trabalha em duas ou mais escolas. As formações continuadas de professores deveriam acontecer no turno de trabalho e ter como prioridade a formação do professor na educação inclusiva, e assim desenvolver a capacidade de melhor lidar com o aluno incluindo-o.

As políticas públicas de inclusão devem acontecer de forma que as capacitações e formações continuadas orientem o trabalho do professor na perspectiva da diminuição gradativa da exclusão escolar, e com isso beneficiar a educação como um todo.

A escola pesquisada tem alguns projetos inclusivos, como o projeto de leitura e escrita, o projeto de raciocínio lógico e outros projetos que a tornam uma escola inclusiva, mas ainda falta a formação dos profissionais em inclusão escolar. 


\section{OBJETIVOS}

\section{Geral}

Conhecer quais são os desafios que o processo de inclusão de alunos em situação de risco social e defasagem idade/série coloca para o contexto escolar e para os profissionais da educação.

\section{Específicos}

Investigar a atual situação dos professores que lidam com essa realidade, buscar junto com eles novas possibilidades de efetivar a inclusão dos alunos em risco social no contexto escolar e na aquisição de conhecimento.

Descobrir quais os possíveis desafios e possibilidades de atendimento para o processo de inclusão escolar de alunos em situação de risco social e com história de fracasso escolar, sob a perspectiva dos profissionais da educação, a partir da análise interpretativa do discurso desses profissionais, em situação de entrevista.

Descobrir as principais dificuldades que impedem a inclusão desses alunos no processo de aquisição do conhecimento e da própria inclusão deles no contexto escolar. 


\section{METODOLOGIA}

\section{1 - Fundamentação Teórica da Metodologia}

A metodologia usada nesta pesquisa foi a Metodologia Qualitativa. É uma pesquisa em que a abordagem busca a opinião e estimula o indivíduo a pensar e falar livremente sobre o tema, esse tipo de estudo faz emergir aspectos subjetivos e suscita a explicitação de motivações inconscientes, de forma espontânea. É uma abordagem que busca revelar opiniões latentes do indivíduo. A abordagem foi em forma de entrevista, direta, pessoal, onde foi elaborado previamente um roteiro de entrevista e cada participante foi entrevistado individualmente. A entrevista foi gravada em áudio de depois transcrita para o computador na íntegra.

\section{2 - Contexto da Pesquisa}

O critério de escolha da escola foi em virtude de ser a escola em que atuo, e de ter um contexto que sempre me instigou e preocupou.

Foram pesquisados professores, coordenadores, pedagogos e a diretora, que atuam na rede municipal de Vitória, estão lotados em uma escola de Ensino Fundamental, onde tem doze turmas, por turno, atendendo do $1^{\circ}$ ano ao $9^{\circ}$ ano, em cada turno. A escola tem uma característica atípica em relação a outras escolas da rede. Tradicionalmente tem um histórico de dificuldades, visto que atende a várias comunidades da periferia de Vitória. Suas vagas são destinadas ao excedente de várias escolas dos bairros do entorno, por estar estrategicamente colocada em um local de fácil acesso a esses bairros. $\mathrm{O}$ índice de alunos em defasagem idade/série é grande, muito mais alto que em outras escolas da rede. A escola está conseguindo diminuir esses índices com um projeto de leitura e escrita, específico para vencer a dificuldade desses alunos, mas não tem sido suficiente, pois os índices ainda continuam altos. O grande desafio é incluir esses alunos no contexto escolar, desenvolvendo sua leitura, escrita e raciocínio lógico.

Além de todas as dificuldades pedagógicas, a escola está situada em um prédio velho, que precisa de constantes reparos, sendo necessário uma grande reforma para que atenda às demandas da escola. A quadra é totalmente inadequada, com acesso apenas pela arquibancada que serve de degrau, dificultando a descida dos alunos, além de não ter cobertura, o que impede seu uso quando o sol está forte e nos dias de chuva, ficando o espaço livre da escola 
restrito.

Os profissionais que estão na escola desde seu início, em 2006, sabem desse contexto, e entendem as dificuldades, mas ao longo desses anos houve uma rotatividade muito grande de profissionais. A cada ano a tipologia da escola muda. Durante os anos de 2006 a 2008, atendia somente as turmas do $2^{\circ}$ ciclo do ensino fundamental, em 2009, passou a atender também as turmas do $1^{\circ}$ ciclo, 2010 passou também a atender as crianças de 06 anos com abertura de duas turmas de $1^{\circ}$ ano. E agora, em 2011, mais duas turmas de $6^{\circ}$ ano. Essas mudanças são significativas, pois faz com que corpo docente mude constantemente. Muitos escolhem a escola, em função da sua localização estratégica dentro do município. E quando se deparam com essa situação atípica, acabam frustrados, pois quando escolhem um local de trabalho sonham com uma escola ideal.

Alguns profissionais entrevistados chegaram na escola no início de 2011, momento em que foram colhidos os depoimentos.

\section{3 - Participantes}

Professor A: Professor de geografia, formado em Geografia pela UFES - Universidade Federal do Espírito Santo, em 1982. Participa das formações continuadas oferecidas pela PMV e também participa de um grupo de estudos independente, que se encontra periodicamente para reflexão sobre a leitura de livros da linha pedagógica. Está na escola desde seu início em 2006.

Professor B: Professor de matemática, formado em Matemática pela UFES - Universidade Federal do Espírito Santo, em 2000. Especialização em Educação Ambiental em 2010. Participa das formações continuadas oferecidas pela PMV. Está na escola desde seu início em 2006

Professor C: Professor de Ciências, formado em Biologia pela UFES - Universidade Federal do Espírito Santo em 1995. Participa das formações continuadas oferecidas pela PMV. Está na escola desde seu início em 2006.

Professor D: Professora do $3^{\circ}$ ano, formada em Pedagogia pela UFES - Universidade Federal do Espírito Santo, em 1997. Especialização em Supervisão escolar, em 2009 fez outra especialização em Psicopedagogia. Está na escola desde 2009, quando chegaram as turmas do $1^{\circ}$ ciclo do ensino fundamental. 
Professor E: Professor de Língua Portuguesa, formado em Letras português/italiano pela UFES - Universidade Federal do Espírito Santo, e mestrado em Línguas português/italiano pela USP - Universidade de São Paulo, em 2000. Participa das formações continuadas oferecidas pela PMV e está preparando um projeto para o doutorado em educação, considera sua própria pratica de estudo para o trabalho uma formação. Até 2010, trabalhava em um bairro da mesma região.

Professor F: Professor de Educação Física, formado em Educação Física em 2004, com especialização em Educação Inclusiva, em 2011. Chegou na escola em 2011. Trabalha em outra escola de um bairro da região.

Professor G: Professora de Educação Física, formada em Pedagogia em 1992 e Educação Física em 1996. Com pós graduação e uma especialização em Biodança, em 2010. Chegou na escola em 2011. Até 2010, trabalhava em projetos sociais da mesma região.

Professor H: Professora de matemática, formada pela UFES - Universidade Federal do Espírito Santo, em 2008, com especialização em PROEJA, no IFES - Instituto Federal do Espírito Santo, em 2010.

Coordenadora: Coordenadora do turno matutino, segmento do $2^{\circ}$ nível do Ensino Fundamental. Formada em Pedagogia, pela FAVI, 2004, com especialização em Gestão Escolar e Ensino Religioso. Atua na escola como coordenadora, desde 2009.

Pedagoga: Pedagoga do turno matutino, segmento do $2^{\circ}$ nível do Ensino Fundamental. Formada em Pedagogia Pedagogia na faculdade de Ciências e Letras de Colatina, 1993, especialização em Docência do Ensino Superior, especialização em Orientação Escolar e em Psicodrama. Chegou na escola em 2010.

Diretora: Formada em Língua Portuguesa, em 1994, com pós graduação em letras, defendendo o tema, Dificuldades e Interferências da Oralidade na Escrita, 2000/01. Atua na escola desde 2006, como professora de Língua Portuguesa e está como diretora desde 2009.

No total, foram entrevistados 11 profissionais, sendo 8 professores, 1 coordenadora, 1 pedagoga e 1 diretora. 


\section{4 - Materiais}

Foram utilizados os seguintes materiais

Gravador de áudio em aparelho celular, onde foram gravadas as entrevistas e usado depois para transcrever as entrevistas para o computador.

Computador durante todo o processo foi utilizado.

Papel A4 para anotações, impressões.

Pen drive para salvar arquivos para impressão.

Roteiro de entrevista, importante para o momento das entrevistas. O roteiro de entrevista foi confeccionado especificamente para o estudo, levando em consideração os objetivos do mesmo.

Termo de consentimento livre e esclarecido.

\section{5 - Procedimentos de Construção de Dados}

A escolha da escola se deve ao fato de eu atuar nela como professora de Arte desde 2006 e conhecer sua problemática, pois sempre dei aulas para todas as turmas do turno matutino. Em minhas aulas tive contato com todos os alunos e percebi que muitos tinham dificuldades de aprendizagem e estavam defasados em idade/série, e acabavam sendo agressivos, inseguros na hora de fazer as atividades de Arte, e com sérios problemas de disciplina, sendo constantemente suspensos por comportamentos inadequados ao ambiente escolar.

Antes de recebermos os alunos do primeiro ciclo do Ensino Fundamental, o número de alunos em situação de risco social e com defasagem idade/série era muito maior, com a diminuição das turmas de alunos maiores também diminuiu o índice, mas continuam chegando muitos nessa situação, principalmente nos $6^{\circ}$ anos. Nas séries iniciais também temos um número significativo, principalmente no $4^{\circ}$ ano, turno matutino, no qual a pesquisa foi realizada.

Procurei entrevistar todos os professores que atuam nas turmas do $2^{\mathbf{o}}$ ciclo do ensino fundamental, mas não consegui entrevistar todos. E também a professora regente da turma de $3^{\circ}$ ano durante o ano de 2010, turma com um numero significativo de alunos na situação descrita. A coordenadora e pedagoga dos alunos do $2^{\circ}$ ciclo e a diretora da escola.

Todos os colegas de trabalho se mostraram solícitos e interessados em responder o roteiro de 
entrevista, sabiam sobre a pesquisa e além das entrevistas colaboraram com seus depoimentos e questionamentos no dia a dia da escola para o desenvolvimento da pesquisa.

\section{6 - Procedimentos de Análise de Dados}

3.6.1 - Análise Interpretativa das Entrevistas

A entrevista individual foi a técnica selecionada para registrar as falas e reflexões dos professores, coordenadores, pedagogos e da diretora da escola. A análise do discurso foi realizada em dois momentos específicos.

No primeiro momento, foi estabelecido categorias de análise a partir do roteiro de entrevista e dos objetivos do estudo. As categorias estabelecidas foram as seguintes:

- $\quad$ Formação profissional

- $\quad$ Alunos com dificuldade de aprendizagem

- $\quad$ Inclusão escolar

- $\quad$ Dificuldade de aprendizagem x exclusão social

No segundo momento, foram realizadas a análise das categorias estabelecidas, nas falas de cada um dos entrevistados, procurando ressaltar as questões comuns a todos. A opinião de cada participante foi citada, pois apesar das opiniões serem semelhantes, um complementa o outro quando colocam sua opinião, pois olham e entendem o aluno de forma diferente, cada um dentro da sua realidade, do seu fazer cotidiano e das especificidades da sua ação dentro da escola. 


\section{RESULTADOS E DISCUSSÃO}

\section{1 - Análise das Entrevistas}

Categoria de Análise 1 - Formação profissional: em um total de 11 entrevistados, todos os entrevistados tem curso superior, 1 tem mestrado, 09 tem pós graduação e 02 que não tem especialização, mas participam de cursos e das formações continuadas,

Somente um profissional tem especialização em Inclusão Escolar, mas não esta foi suficiente, aos olhos do professor. A formação dos demais profissionais não lhes deu ferramentas específicas para trabalhar com as questões de inclusão escolar e dificuldades de aprendizagem. Mesmo assim os profissionais fazem um trabalho individualizado com as crianças, a partir das ferramentas profissionais que têm.

Categoria de Análise 2 - Alunos com dificuldades de aprendizagem: Todos os profissionais entrevistados têm, em seu cotidiano escolar, alunos com dificuldades de aprendizagem, e todos os professores os têm em suas turmas. Todos disseram ter um olhar diferenciado sobre os alunos que têm dificuldades de aprendizagem e procuram fazer um atendimento individualizado com atividades diferenciadas para os alunos.

A diretora, diz que a escola de um modo geral, tem se organizado para avançar os alunos com dificuldades de aprendizagem e defasagem idade/série, tanto que dentro da organização curricular já foi previsto horários para os professores trabalharem de forma diferenciada e também projetos específicos para atender a esse grupo de alunos, como a Oficina de Leitura e Escrita.

Temos a reclassificação, que a escola sempre trabalhou sob essa perspectiva, de que precisava ajudar esses alunos, no plano de ação já tem o projeto que foi idealizado especificamente para esses alunos, que é a oficina de leitura e escrita, e agora conseguimos avançar nisso garantindo na grade projetos para os professores que tem uma carga horária sobrando para trabalhar com os alunos que tem um grau de dificuldade.

Quanto ao comportamento, de um modo geral são dispersos em sala de aula, não entendem o que o professor está falando, do que se trata a aula e acabam sendo mais agressivos e gerando problemas de disciplina, a escola tenta envolver a família.

Normalmente é dirigido ao pedagogo que faz a orientação inicial, chama a família, conversa, quando é detectado que tem necessidade algum problema físico, as vezes o aluno não faz atividade porque tem dificuldade visual, então a escola encaminha 
para a Unidade de Saúde para que se façam os exames. Temos trabalhado assim. Se percebe alguma dificuldade cognitiva também fazemos o encaminhamento, já fizemos encaminhamento para a APAE, para o psicólogo para poder detectar qual a dificuldade que o aluno tem para que possamos atender dentro das possibilidades da escola, e geralmente chamamos a família para conversar também.

A pedagoga, no atendimento ao professor, propõe a elaboração de atividades diferenciadas, e procura fazer um levantamento, junto com ele, dos alunos em dificuldades, e assim encaminhar aos estudos no contra turno, pois a escola tem uma professora para atendê-los, e dessa forma, poderem ter pelo menos uma boa base, pois muitos deles já estão em $7^{\mathrm{a}}$ e $8^{\mathrm{a}}$ séries e não têm uma base alfabética fundamentada.

\begin{abstract}
A maior dificuldade nossa é essa, porque quem não tem essa base alfabética, não consegue ler uma questão matemática e compreender. Essa é nossa grande questão, que esse menino seja letrado, e que o letramento seja uma base sólida. [...] Eles se sentem fora do meio, totalmente excluídos, porque você tem que incluí-los, eu tenho um "algo mais" em orientação vocacional que é meu enquanto pedagoga, com o professor eu trabalho com a pedagogia de forma normal que é o atendimento ao professor, e com o aluno eu busco muito esse "que" vocacional usando um pouco de psicodrama também, e ouço muitos relatos do tipo: "professora ninguém na minha família deu certo, eu daqui a um tempo vou ter que parar de estudar para trabalhar." E eu venho com aquele trabalho de elevar a auto estima, dizendo que se ninguém na família deu certo, ele precisa dar, dizendo: você vai ser o ponto de apoio da sua família. Hoje quem mora com você? "Ah eu, minha tia e minha mãe." E quem trabalha lá? "Minha tia e minha mãe." E o tipo de trabalho que elas tem geralmente são trabalhos braçais, que exigem mais força, e pergunto se é isso que ele quer pra ele. E vou estimulando a estudar a tentar fazer melhor, mostrar que podemos fazer a reclassificação mas tudo isso depende dele querer, dele estudar um pouco mais. Estamos o tempo todo nesse embate, fazendo que ele levante a auto estima para que ele tenha vontade de crescer.
\end{abstract}

Quando os alunos não fazem atividades em sala, a pedagoga solicita que os professores encaminhem-nos para sua sala e então faz um trabalho específico, "de forma que ele se sinta dentro do contexto, para que ele possa dizer o que pensa, pois muitas vezes ele não tem capacidade de dizer ou escrever da forma que pensa."

O professor A diz que para esse aluno ser devidamente incluído o "poder público municipal tem que dar o apoio devido, com material que seja específico para cada especificidade do aluno, esses alunos tem que ter um tempo na escola diferente dos outros, a parte pedagógica tem que conversar de forma diferente sobre cada um." Pois tem aluno com dificuldades de aprendizagem, bom comportamento, força de vontade de superar suas dificuldades, e ele precisa de estímulo adequado. Também precisa de informações sobre a situação do aluno, e com isso buscar um melhor atendimento, exigindo o que ele pode render em termos de possibilidades e assim fazer com que ele possa superar suas dificuldades.

O professor B que é da área de matemática, diz que tem se articulado junto com a escola de 
forma a viabilizar um trabalho diferenciado, articulando novos espaços para que esses alunos consigam adquirir um conhecimento básico de forma que consigam acompanhar o restante da turma. No geral eles ficam muitos distantes da turma ou são agitados demais, se esse tratamento diferenciado não funciona procura chamar a família para entender melhor o contexto do aluno e assim juntos buscar melhores alternativas.

O professor $\mathrm{C}$ diz que tenta fazer um trabalho diferenciado em relação aos outros alunos, mas muitas vezes não consegue devido a grande quantidade de alunos na sala, mas vai até a carteira do aluno, procura se aproximar mais, dando a eles um atendimento individualizado e se aproximando mais do aluno. Pois muitas vezes eles se comportam de forma inadequada por terem dificuldades, tentam preencher o tempo com brincadeiras e até agressividade, e uma maior aproximação evita isso.

O professor $\mathrm{D}$, que é regente de sala na turma de $3^{\circ}$ ano, diz que, para que os alunos avancem faz um trabalho diferenciado de acordo com as necessidades e nível de aprendizagem de cada um. Que é importante também motivar e elevar a auto estima do aluno valorizando-o sempre. Os alunos com dificuldades de aprendizagem, geralmente são os mais levados da turma, são os que atrapalham o andamento das aulas, por não saber eles acabam tumultuando. Quanto aos alunos que não fazem atividades em sala de aula.

Procuro colocá-lo o mais próximo possível, oferecendo atividades que ofereçam um certo grau de dificuldade mas que são possíveis de serem resolvidos pelo mesmo. É necessário cativar o aluno, através da afetividade e da motivação conseguimos grandes resultados.

O professor E, como chegou a escola recentemente, fez uma avaliação diagnóstica, com as turmas que trabalha, para saber das dificuldades de leitura e escrita, e assim encaminhar os que precisam de reforço para a oficina de leitura e escrita, além da aula extra que tem junto com a outra professora de língua portuguesa. Como a estrutura da sala de aula não permite trabalhar as dificuldades individuais em sala, ele vai se revezando com a outra professora para atender aos alunos nesse horário extra. Até atender a todos de forma individualizada.

Sentiu uma certa resistência por parte dos alunos que não foram alfabetizados devidamente, na sua grande maioria tem vergonha.

O aluno do reforço que vai ser acompanhado pelo professor, ele sabe o motivo do acompanhamento. Os outros foram para o jardim da escola, tinham feito tudo, então por mais que o professor evite esse tipo de situação de separação ela existe e vai haver, a turma que fez a atividade foi e os que não fizeram ficaram na sala. Como é que eu resolvi isso? Para evitar que eles se sintam mais uma vez excluídos, eles ficaram hoje, mas da próxima vez eles irão para o pátio e os outros ficarão. Então uma coisa que nunca deve se fazer é que eles não se sintam excluídos todas as vezes. 
Explicar o projeto pra toda a turma, e dizer vocês ficaram mas um outro dia os outros que foram ficarão e vocês irão.

Quando os alunos não se interessam pelas aulas e não fazem as atividades o professor procura estimular o máximo possível, com filmes, músicas, comentários e o uso do computador, apesar da escola não ter uma boa estrutura neste sentido ele leva seu próprio material.

Estou trabalhando a história do samba, um pouco do samba, um pouco de ritmo e de um modo geral eles se envolvem. E mesmo assim aqueles que não se envolvem eu procuro conversar com a pedagoga, com a equipe da escola pra ver qual a situação daquele menino ou menina e ver como eu posso atuar junto com a equipe. Nesses casos eu não procuro tomar uma atitude sozinho não, até porque eu não conheço a história de cada um, então procuro conversar sobre isso com a escola e junto com os pais também.

Professor G diz que antes de tudo conversa com a equipe técnica da escola, coloca que o objetivo das aulas de Educação Física não é a competição, e sim o desenvolvimento psicomotor. Procura mostrar que ninguém nasce sabendo.

Eu tenho um livro que fala sobre isso e eu conto, não importa a idade, pois o livro é uma literatura infanto juvenil, ele fala que a gente aprende a andar, aprende a comer aprende a pular corda e quando descobre já está fazendo as coisas e é uma história que mostra que a gente vai aprendendo errando, erra, acerta, e tudo isso com a supervisão do professor.

Procura dar um tratamento diferenciado para que todos saibam que a condição é a mesma para todos e para isso basta tentar, que aprende quem tem vontade, e que é no erro que se aprende. Se a criança não errar ela não aprende, mas que eles têm medo de arriscar, têm medo do que o outro vai falar e que vai apontar o erro. E com isso vão ficando retraídos.

Querem participar mas têm vergonha, e é nesse momento que eu faço uma conversa geral com eles, eu evito essa coisa de competitividade, mas é muito difícil. Procurando a cooperação, a reflexão, não deixo passar, e aquele que tem dificuldade, ele mesmo zomba do outro. Tem um da terceira série que eu achei incrível, o aluno tem dificuldade mas aponta a dificuldade do outro, ele vê a dificuldade dele na dificuldade do outro, mas não coopera com o outro, ele critica o outro, e eu fíco olhando essa situação e o chamei. Olha vem cá, você não está mais ou menos na condição dele porque você está criticando ele? E mostrei que é assim que se faz, que tem que errar pra aprender.

$\mathrm{O}$ professor $\mathrm{H}$ diz que procura trabalhar de forma contextualizada, trazendo o meio deles pra dentro da sala de aula. Que é complicado, muito difícil, mas tenta, pois "estamos tendo ajuda agora, que não tinha antigamente." Procura valorizar o que eles tem de conhecimento e trazendo isso para o contexto de sala de aula. 
Muitos são dispersos, não têm comprometimento, muita falta de interesse, e como eles têm dificuldades, para ele não interessa aquilo. São descompromissados, ou muito caladões também, saem demais para beber água.[...] Quando não querem fazer as atividades, eu geralmente me sento do lado deles, pergunto sobre a dificuldade, tento trazer o tempo todo pra aula, é muito difícil um aluno ficar sem fazer nada, até porque eu não deixo, eu sempre fico no pé deles, então não fica aluno na minha sala sem fazer atividade.

A coordenadora diz que a escola tem tentado buscar alternativas junto com a equipe técnica.

A gente tem tentado fazer algumas interferências junto com os alunos, com a pedagoga e coordenadores. Trabalhando os alunos e a família, na orientação, quando percebemos que eles não conseguem dar conta da sala de aula e acabam dando problemas de disciplina e vice versa. A gente tenta fazer um trabalho para que eles possam ficar em sala de aula e mostrando que eles podem aprender.

Categoria de Análise 3 - Inclusão escolar: Dos onze profissionais entrevistados, somente um tem uma especialização em Inclusão Escolar, as respostas dos profissionais mostram que todos sabem o que é, mas não sabem exatamente como proceder. E cada um inclui de acordo com suas concepções.

Para a diretora da escola, Inclusão Escolar é um conceito complicado e acha que,

Incluir seria você dar condições para que as crianças estejam na escola com qualidade dentro dessa escola, sejam recursos materiais e também cognitivos. Seriam incluir também aqueles que têm dificuldades familiares e a gente não consegue fazer essa inclusão total porque a escola também está amarrada a uma série de situações. A gente também não consegue incluir totalmente. Teria que ter uma política mais séria e com isso nós teríamos condições de incluir totalmente.

Para ela, o maior desafio da Inclusão Escolar hoje passa pela política de inclusão estar voltada somente para os alunos que têm NEE, comprovadas com laudos, e com isso chegam equipamentos para montagens de salas multifuncionais, inclusive a escola recebeu uma série de equipamentos e deve continuar recebendo, e os alunos que não são amparados por laudos médicos, e têm dificuldades não são atendidos no laboratório.

Com relação aos alunos que não têm laudo médico, eles não são amparados, não são assistidos nesse laboratório. A escola recebe dupla matricula para o aluno que tem laudo médico e que está inserido na educação especial, ele entra no censo duas vezes, ele conta com duas matriculas e a escola recebe recursos para essas duas matrículas. O setor de educação especial exige que o pai traga em dois horários, frequenta a sala normal num horário e o AEE no contra turno para que possa garantir isso daí. Agora com aqueles outros alunos que eu acho que são o maior desafio da escola, que é aquele que não tem laudo, que a gente não sabe qual é a dificuldade dele, mas que a gente sabe que tem uma dificuldade especial, não tem aquelas que garantem o acesso ao laboratório, mas tem outras dificuldades, e detectar essa dificuldade é o grande desafio da escola, pois a escola não tem condições de acompanhar pois por mais que a gente faça, tem sempre alguma coisa que está faltando. E de um modo geral esses alunos acabam sendo excluídos, pois são alunos que ficam reprovados repetidas 
vezes, e os professores até pensam porque a escola não transfere esse aluno, muitas vezes o professor não se desafia a trabalhar, eu diria até que alguns pedagogos também querem trabalhar com o aluno certinho, com o aluno ideal, o aluno que produz, que segue regras, que vem bonitinho e cheirosinho para a escola. Aquele aluno que não segue esse padrão, normalmente é colocado de lado, infelizmente, porque nós sempre tivemos um grande quantitativo desses alunos, esse ano estão chegando mais, acabamos de receber essa semana três alunos, que estavam excluídos, uma menina de sete anos, um menino de nove e outro prestes a fazer doze anos em abril que nunca foram à escola, e quando eu falei da situação, assustou, porque assusta mesmo, que aluno é esse, de onde que ele vem, e porque nunca foi a escola. É um desafio que está chegando para a gente e como vamos atender a essas crianças, eu conversei com o grupo e ficou estabelecido que as crianças serão matriculadas no primeiro ano é um desafio pois no primeiro ano nos temos crianças de seis anos, e todos os três fogem dessa faixa etária. Três irmãos eu pedi que fizessem um trabalho diferenciado, que as crianças viessem no contra turno para acelerar o processo de alfabetização deles para no segundo trimestre reclassificar pelo menos os dois mais velhos para uma série mais adiante, para não perder muito tempo, conversei com o pai que acha difícil trazer as crianças nos dois horários porque eles não saem de casa sozinhos, a mãe trás e leva. A impressão que eu tive foi de que eles viviam reclusos, são moradores do Morro do Macaco, e segundo informações foi de que viviam em meio das pedras como se fossem bichos. No primeiro contato com a professora ela me disse que são crianças tranquilas, o desafio é convencer a família de que eles perderam muito tempo e que eles precisam recuperar esse tempo, e aparentemente as crianças querem, mas eu notei uma certa resistência por parte do pai, a informação que eu tive é de que ele é muito controlador, quer os filhos constantemente sobre os olhos dele e por isso não deixou as crianças estudarem. Alegação dele é que nunca conseguiu vaga. Agora uma criança de doze anos que nunca conseguiu vaga, no município de Vitória? É complicado!

Para o professor A inclusão escolar é o indivíduo que tem dificuldades, problemas, ter alguma chance dentro do universo que ele está.

Significa você incluir a pessoa dando a oportunidade devida pra ele render. Incluir é respeitar todos os limites que ela tem, ignorar todos os chavões que a sociedade usa pra colocar a margem. A escola tem que dar a pessoa possibilidades para ela resgatar o seu potencial. Ela precisa ter a chance, ter a oportunidade de aprender como os outros, até porque a sociedade depois vai cobrar, e num processo contínuo ela vai participar do meio social, e ela precisa ter a chance também no social, no trabalho, naquilo que ela será capaz de realizar. A inclusão é dar as condições devidas, no tempo devido, da pessoa aprender.

Coloca também a importância do envolvimento da família, a importância do apoio pedagógico e do poder público, pois o professor com salas lotadas não consegue dar o apoio devido aos alunos com NEE.

Acho que a cargo horária do professor está muito pesada, o poder público tem que ter um olhar sobre isso, para que o professor possa ter tempo de planejar a interação com esses alunos, dar um tratamento diferenciado de forma que eles possam chegar ao nível dos demais.

Para o professor B, Inclusão escolar "seria propiciar para qualquer pessoa a possibilidade de 
estar dentro de um espaço de conhecimento." Não é fácil pois os professores não estão preparados para trabalhar de forma inclusiva, no seu curso de graduação esse assunto não foi trabalhado.

\begin{abstract}
Então quando o professor chega pra trabalhar na escola que ele se depara com alunos com necessidades especiais, alunos com problemas sociais, toda essa problemática, vai ser tudo novidade para o professor, porque na graduação a gente não vê isso, é um desafio, a gente vai aprendendo na prática como trabalhar inclusão em sala de aula. Não tive formação em relação a isso nos encontros de formação continuada em que já participei, oferecidos pela PMV,e pela PMS, em nenhum momento a gente discutiu sobre inclusão, e não vejo colega conversando a respeito disso também, então de modo geral, eu percebo os alunos com dificuldades de aprendizagem sendo tratados como se eles tivessem o mesmo rendimento dos demais alunos, porque não vejo um diálogo na escola, na formação, na escola com os professores não é discutido, é uma coisa que me preocupa e que não vejo discussão dentro da escola. É um desafio e a gente tem que dar conta disso sem ter orientação, formação.
\end{abstract}

Para o professor C, para existir a inclusão escolar é preciso o apoio da família. A escola tem que tentar inserir o aluno na sociedade de forma que ele possa caminhar sozinho. O desafio é se aproximar mais do aluno de forma que ele possa acompanhar o conteúdo que é transmitido em sala de aula.

Para o professor D, Inclusão Escolar é fazer com que o aluno sinta-se parte, é fazer com que ele participe dando o retorno de que é capaz naquele momento, buscando sempre atingir índices mais elevados de aprendizagem. Os desafios são muitos e "são muitas as diferenças que temos que lidar no dia dia de sala de aula, nós temos o aluno em vários níveis de aprendizagem, e o mais difícil é fazer o atendimento individualizado em uma turma tão heterogênea."

O professor E, diz que Inclusão Escolar é um termo muito amplo e define a exclusão pela inclusão.

Pra mim inclusão é o domínio das duas habilidades máximas, a leitura e a escrita, quem domina a leitura e lê o suficiente pra interpretar um texto e interpretar a realidade a sua volta está apto dar sua opinião. [...] Mas alunos que não dominam a leitura e não participam ativamente das aulas marcaram na sua avaliação diagnóstica a opção em que diz que o grupo étnico que mais sofre preconceito no Brasil e isso foi interpretado por eles, naturalmente porque veem jornal, televisão, eu não acredito que essa seja uma interpretação somente da escola, pois dizer que negro e pobre no Brasil é praticamente a mesma coisa. E isso não é só visto na escola.

Para o professor o grande desafio é transformar os alunos em leitores, dando mais oportunidades de leitura de livros diversos, mas sempre pautando na escrita, na reescrita, voltando sempre no mesmo texto, de preferencia ler um livro do início ao fim e assim combater um dos principais problemas dos livros didáticos.

Nos livros didáticos, a gente tem acesso a literatura em pedaços então a gente chega 
à Universidade, sem saber ler, sem saber interpretar, sem saber a produzir texto. Eu já to combatendo isso desde o ensino fundamental, a gente lê um livro e vai do início ao fim, comentando as partes, vendo se tem uma narrativa, as partes da narrativa, do inicio ao fim.

Para o professor F, Inclusão Escolar seria "dar a todos o mesmo direito de participar das aulas, das atividades." Ele tem uma especialização em Inclusão Escolar mas disse que foi superficial, buscou por conta própria mais estudos sobre o tema. Segundo ele é difícil trabalhar inclusão na sala de aula, pois o próprio aluno se exclui, ele não quer mostrar para a turma que tem dificuldade e não permite que você o ajude e com isso fica difícil se aproximar, trazer esse aluno para participar das aulas, pela vergonha de ele tem de assumir suas dificuldades.

Para o professor $\mathrm{G}$, a escola tem dificuldades e incluir, e que na tentativa de incluir acaba excluindo, pois não basta o aluno estar frequentando a escola e a sala de aula para estar incluído. Muitas vezes ele está na sala, mas excluído pelos colegas, que vão rejeitando colocando apelidos, nessas horas é necessária a conversa.

\begin{abstract}
É refletindo junto, por exemplo se um está com dificuldades e saiu da aula, eu deixo naquele momento, mas depois eu venho, vou buscando sempre, incluindo sempre, sem a competitividade, eu estou aqui pensando nas aulas de educação física. $\mathrm{Na}$ minha aula é isso, é refletindo junto, se eu não refletir e deixar passar... A questão do gordo por exemplo, eles mesmo se colocam apelido, tem um aluno que é enorme e chama o outro de melancia e o outro chama ele de jaca. Nessas horas eu chamo pra refletir. Mas, não da pra incluir sozinha, a escola precisa trabalhar na coletividade, se não tem um trabalho coletivo é complicado. A gente tenta mas é muito complicado temos muito que avançar ainda.
\end{abstract}

Para o professor G, Inclusão Escolar ainda é uma coisa desconhecida na educação, mas acha que seria trabalhar crianças diferentes num mesmo ambiente, tentar fazer isso, pois é uma tarefa difícil. "Trabalhar diversas realidades e diferenças numa sala de aula." Acredita existir ainda muita discriminação, e a exclusão acaba seguindo o aluno, ano a ano, pois as dificuldades não são superadas, e acaba levando o estigma de "burro" pelos colegas, o grande desafio é tentar resgatar a auto estima. Como professora de matemática precisa voltar à base do raciocínio para poder avançar com o aluno em dificuldade, e essa não é uma tarefa simples quando, nas séries finais do Ensino Fundamental, o aluno ainda tem defasagens que não foram superadas.

Inclusão escolar, na concepção da coordenadora da escola, seria trabalhar o aluno de forma que consiga respeitar as diferenças de cada um. Perceber essas diferenças dentro da turma e com isso incluir os alunos, não só os amparados por laudos, mas os que têm dificuldades sociais e familiares, dentro do espaço escolar, para que ele possa compreender o espaço e a 
função da escola.

Quando você pensa em incluir um aluno não vai estar envolvendo-o apenas naquele espaço, é preciso envolver todo o grupo, toda a turma. Você tem em uma turma alunos que acompanham o desenvolvimento normal da aula, alunos que precisaria avançar pois captam rapidamente o que é passado e também alunos com dificuldades que precisa que você volte no conteúdo. São desafios que trás ao professor, e é nessa hora que ele precisa ter um suporte para trabalhar na turma com atividades diferenciadas, e assim fazer com que os alunos consigam chegar os objetivos previstos para aquela série. $O$ professor precisa ter apoio pedagógico para desenvolver melhor seu trabalho. Minha função é dar o suporte ao professor na sala de aula, pois muitas vezes ele não dá conta de dar atenção a esse ou aquele aluno, a diversidade na sala é grande. A gente vai percebendo essas dificuldades de comportamento e trabalhando isso momento que surge.

A pedagoga acredita que a Inclusão escolar não acontece da forma como deveria. Que garantir a permanência de um aluno com NEE dentro da sala de aula, com pessoas da idade dele seja insuficiente.

Eles não estão incluídos, estão colocados dentro de turmas, é feito algum trabalho com eles mas não estão ainda incluídos. Você pode fazer um questionamento com cada um deles, saber com se sentem, e vão te dizer que se sentem parte, e não são o grupo. Então isso par mim não é incluir. Ele não está se sentindo como, ele está se sentindo parte. Ele precisaria de ter domínio e capacidade de entender. A defasagem dele poderia ter sido revista anteriormente com uma fono, com um psicólogo, com alguém que o atendesse em outro horário. E aí ele poderia ser incluído de uma forma globalizada, eles não se sentem bem por conta disso, veem que o colega lê, escreve, que faz e acontece e eu não faço nada disso. Os que estão incluídos com laudo médico, eu vejo uma felicidade por estarem aqui dentro do meio escolar, isso pra mim é claro, é uma coisa que trás um sentimento real de inclusão, mas a gente precisaria de muito mais apoio pra ele. Os professores e pedagogos ainda têm muito a conquistar, pra isso realmente fluir.

Para ela o maior desafio da escola hoje é lidar com a Inclusão sem ter formação em Inclusão.

Os maiores desafios é lidar com algumas doenças que precisam de conhecimentos que eu ainda não domino, essas que são comprovadas e que muitas vezes vem com laudo. Agora quando você percebe que o aluno tem problemas e que muitas vezes não tem laudo, e a gente precisa de conciliar ele no dia dia, e na hora de avaliar esse aluno ele é avaliado igual. Ele tem que ser avaliado igual? Ele pode ser avaliado igual? Ele deve ser avaliado igual? Essas são questões em que o professor não está preparado pra resolver isso, eu enquanto pedagoga não estou preparada pra responder isso, eu não tenho formação e todos nós deveríamos ter formação pra poder responder isso, agora hoje! E eu tenho tempo de fazer essa formação? Infelizmente não! Eu queria? Urgentemente, pra ontem! Porque eu acho que todos nós deveríamos ter essa formação, pra ter capacidade de lidar com esse menino de incluí-lo.

Categoria de Análise 4 - Dificuldade de aprendizagem x exclusão social, nessa categoria de análise vamos analisar se a dificuldade de aprendizagem está ligada ou não a um histórico de exclusão social.

Para a diretora da escola, a dificuldade de aprendizagem não necessariamente estaria ligada a 
uma estória de exclusão social, as pessoas são diferentes e muitos fatores contribuem para a dificuldade de aprendizagem. "Eu acho que existem muitas coisas que contribuem, têm crianças aqui que não têm tantas perspectivas e que conseguem produzir."

Para que aconteça a inclusão de alunos em situação de risco social, a diretora disse que deveria ter uma rede que atendesse a esses alunos, muitos vem encaminhados pelo Centro de Referencia da Assistência Social - CRAS, são famílias que precisam de apoio financeiro, cesta básica, acompanhamento médico e psicológico, além desses serviços é preciso que atendam em forma de rede, integradas com a escola, pois ter acesso à família muitas vezes é uma tarefa impossível.

Precisava que os equipamentos municipais fizessem uma rede que de fato funcionasse, pois essas pessoas com certeza precisam de assistência, com relação a recursos financeiros, um acompanhamento mais sistemático. Tanto é, que têm pais que vem encaminhados pelo CRAS e praticamente abandonam o filho na escola, vem, matricula e não acha necessidade de acompanhar. Eu acho para essa rede social funcionar precisava que fosse uma coisa realmente integrada, um atendimento mais refinado, pois as ações se perdem muito no tempo. No dia a dia os atropelos são muitos e a gente não dá conta de tudo.

Ela também coloca que a escola está muito sozinha para resolver questões tão complexas, que por mais que a ajuda chegue, acaba não se efetivando pois a rede não se fecha, alguém deixa de fazer sua parte. Ela conta um caso em que teve que acionar a rede para um atendimento e não tem um histórico do desfecho, porque as ações se perdem.

Nós tínhamos aqui o aluno Gabriel, você está lembrada pois você deu aulas para ele no ano passado. Ele sempre foi muito problemático, e a mãe dele, na minha opinião, não aceitava a doença do filho, mas muitas vezes ela usava a doença para proteger o menino. Foi matriculado pela manhã, mas não deu certo pois ele tomava remédio controlado e não conseguia acordar cedo, depois descobrimos que ele ficava até de madrugada na rua, a mãe nega, claro! Passamos para a tarde para ver se conseguia acompanhar mas continuou com um histórico de faltas. No ano passado, a situação se agravou, porque ele continuava desafiando os professores, batendo de frente, até ameaçou os professores. Enfim, fizemos a tal da rede, participaram da reunião Ministério Publico, Unidade de Saúde e escola. O Conselho Tutelar, como sempre, não apareceu, CRAS, SEME, então ficou combinado o seguinte: ele voltaria a fazer o atendimento com a psicóloga, pois, anteriormente, a mãe era muito resistente a esse atendimento, já ficou agendado um horário para esse atendimento. O CRAS ficou de fazer atendimento para a mãe e os irmãos, pois precisavam ser acompanhados também. O Ministério Público se comprometeu a fazer um estudo do caso e encaminhar para o promotor. Conclusão, o menino a voltaria a frequentar as aulas, mas a mãe não queria que ele ficasse nessa escola, a SEME dizia que ele deveria ficar aqui pois já tínhamos um histórico do aluno, o menino foi no atendimento psicológico sozinho, a mãe não acompanhou, e voltou mais uma vez, ela não foi no atendimento ao CRAS, falou que não iria, o Ministério Publico, não foi fazer o estudo com ele. Antes a escola já tinha para ele um atendimento no CAPICIM, que é da Secretaria de Saúde, mas a mãe se recusou a levar, nós marcamos uma reunião, ligamos mas falaram que ela estava dormindo e não foi. A assistente social, marcou um outro horário que ela pudesse e ela também não foi, e 
falou que não iria levar pois o menino já tinha médico, e toda a assistência que ele precisava, mas foi na SEME e falou que não marcava médico pois estava difícil conseguir, foi aí que resolvemos fazer essa rede para acompanhar, e a a secretaria de saúde iria acompanhar mais rotineiramente o rendimento do Gabriel. Finalizando, ele não voltou mais a estudar na escola, ela tirou ele da escola agora em janeiro, mas no final do ano ele não frequentou as aulas, ela falou que ele não iria voltar para a escola, chegou a vir uma vez mas acabou indo embora, arranjou problema no dia. E ela não aceitava, mas desconfiávamos que ele estava envolvido com drogas, pois os amigos dele usavam ou vendiam, a mãe negava, mas a questão é que ele estava cada vez mais agressivo, enfim eu acho que a assistente social cumpriu a parte dela, mas o Ministério Público, que era parte desse processo, não cumpriu a dele, tirou o corpo fora. Porque, para esse menino ser assistido, a mãe precisava, também ter assistência, precisava se conscientizar de que ela precisava fazer com que o menino fosse assistido, mas ela deixava os remédios por conta dele tomar os remédios que ele já estava grande e poderia fazer isso sozinho, ele dizia que não precisava de remédios pois não tinha problema nenhum. Poderia ter funcionado a rede mas cada um deveria ter feito a sua parte. O Ministério Público, que tinha o papel mais importante, deixou de fazer a parte dele. Hoje eu não sei se ele continua a fazer o atendimento no psicólogo, pois a mãe retirou ele daqui. Também não sei se a SEME continua acompanhando o caso dele.

A pedagoga da escola pensa que o problema é social sim "porque as possibilidades, são muito menores para aqueles que tem um histórico de exclusão.” Conta que trabalhou muito tempo em escolas particulares e que quando um problema era detectado, a família "corria na frente" com atendimento adequado ao problema. Na rede pública as coisas acontecem muito devagar as ações se perdem no tempo e a criança cresce sem sanar os problemas que poderiam ser resolvidos com um pouco mais de ação.

Para resolver o problema, ela acredita que os profissionais da escola deveriam estar preparados para lidar com toda essa problemática, pois, dentro da rede em que atuamos existe uma equipe que estuda para isso, para prestar assessoria às escolas, mas que é muito pouco e essa ação não chega aos professores,

Primeiro deveríamos ser capacitados como profissional, para depois junto com o pedagogo pensante, ajudar o professor a tentar. $\mathrm{O}$ que acontece dentro de uma sala de aula é que temos pessoas diferentes com linhas de pensamentos diferentes. Deveríamos ter condições de levar para o professor suporte e opções de se trabalhar melhor com esse aluno.

O professor A acredita que boa dos alunos em dificuldade de aprendizagem são fruto de exclusão social, sim, pois formamos uma sociedade de exclusão, e a escola é um parâmetro para medir a sociedade, e se não estiver atento, a exclusão acontece dentro da escola. A escola precisa ter um olhar diferenciado para resolver dentro, os problemas que surgem fora. Problemas esses, nem sempre causados pela família, mas muitas vezes por grupos diversos em que o aluno começa a se inserir e que o leva a não se sentir motivado a aprender o que a escola ensina. Temos situações em que o menino está sob liberdade assistida e só vai à escola 
por determinação judicial. Frequentam mas não se apropriam do conhecimento, não participam das discussões, acabam migrando para o ensino noturno em função da complexidade de mantê-los no ensino regular. Para que a inclusão desse aluno aconteça precisa de um apoio maior do poder público.

\begin{abstract}
Bom, primeiro o poder público tem que saber que o professor precisa ter uma formação especial para lidar com essas questões. Ele tem que dar a chance, devida, no tempo devido, para realizar uma preparação e assim se engajar nesse tipo de trabalho, não adianta eu saber da doença, eu preciso saber do remédio para tratar tal doença, e aplicar o remédio para tratar da doença implica em que eu também conheça da doença e conheça o remédio. Então se eu tenho o problema dos alunos envolvidos com a questão da droga, aqui mesmo no ensino regular, que nós já vivemos isso aqui, você detecta que um aluno está envolvido na droga, nós não temos sequer dentro da escola hoje, uma assistente social que possa ir a casa dele que possa saber onde ele mora, só temos o pedagogo para fazer esse papel dentro da escola, além do mais depois de detectado o problema, têm famílias que não vem na escola, teríamos que ter um encaminhamento, e nesse caso específico, para quem? Então a escola não tem pernas para alcançar isso. O poder publico deveria oferecer condições, o tratamento e o encaminhamento para se resolver isso. Eu não visualizo outro caminho para tratar dessas questões sem o poder público, municipal, estadual e até federal para resolver a questão. O poder federal tem tido um olhar sobre isso ultimamente, mas até isso alcançar a área municipal é um grande caminho a se percorrer. E, enquanto isso não acontece, os alunos acabam jogados no meio da rua envolvidos com toda a sorte de problemas, morrendo muito cedo e cada vez mais correndo o risco de envolvimento com drogas. E se envolvem mesmo, pois os dias são curtos e acabamos perdendo muitos deles.
\end{abstract}

Para o professor B, o governo não oferece condições para a escola trabalhar com as demandas sociais. A escola deveria conhecer o meio ao qual está inserida e com isso minimizar as questões da exclusão social no contexto escolar. Estimular a participação da família na aprendizagem do aluno, pois a distância dificulta o rendimento, o apoio é fundamental, buscar também outras parcerias para resolver os problemas. A escola poderia oferecer outras opções como esporte e oficinas, mas percebe que não está preparada para esse tipo de atendimento.

O professor C assinala que a participação da família é muito importante na educação do filho, se a família não mostra para a criança a necessidade de estudar, vai ficar mais difícil para a escola desempenhar o seu papel, e uma família excluída socialmente, vai acabar relegando a educação para um plano menos importante, e com isso a situação de desigualdade vai se perpetuando, o aluno que não avança hoje vai acabar tendo um trabalho informal e continuar ganhando pouco, ou até mesmo sendo aliciado pela "facilidade" do tráfico de drogas, como muitos de nossos alunos. Sobre como deveria acontecer a inclusão o professor sabe que precisa acontecer, mas não sabe exatamente como.

A inclusão, ela deveria acontecer de forma que traga para esses alunos a oportunidade de estar tendo conhecimento, trazendo para eles uma forma de facilidade para eles adquirirem esse conhecimento, e incluir esses alunos com 
certeza não é fácil, porque nós, eu não tenho capacitação para estar tendo um conhecimento maior em relação a isso, mas o que eu penso que nós não podemos excluir ninguém, então temos que trabalhar de uma forma para estarmos sempre tentando incluir esse aluno para que ele não se perca no futuro dele.

O professor D acredita que a dificuldade de aprendizagem está ligada a um histórico de exclusão, as crianças acabam não tendo o devido apoio dos pais, que muitas vezes são analfabetos, e ficarem com avós, sozinhos em casa e consequentemente nas ruas o que os leva ao desinteresse pela escola. Segundo ela, a escola deveria ser melhor assistida, com assistente social, psicólogo, psicopedagogo, para um melhor atendimento e acompanhamento dos alunos nessa situação, pois os profissionais da saúde não dão conta da demanda da unidade. "Precisamos de profissionais que atendam a demanda da escola." O professor E cita Paulo Freire quando diz que a educação na América Latina passa pela questão política. Diz também que a própria escola pratica a exclusão em algumas situações sem perceber.

\begin{abstract}
Quando eu chego numa sala onde se constatou que há um grande problema de aprendizagem e eu vejo o quadro cheio de texto e que essas mesmas crianças que ainda não dominaram a escrita são constrangidas a copiar do início ao fim, e o que é pior, aqueles textos muitas vezes estão nos livros didáticos, aí está uma pratica de exclusão, porque as crianças passam a odiar a escrita, eu também odiaria. O professor que faz isso muitas vezes nem tem noção que está praticando a exclusão. A escola não estimula o professor, não há formação devida de professor, são poucos os que estudam, você sabe disso, é grande a dificuldade de diálogo entre o professor que não pesquisa e o professor pesquisador. Não é verdade? Então pratica a exclusão. Quando eu percebo que o professor não percebe o excluído, se coloca numa posição de funcionário, trabalhador da escola, na condição de assalariado, que tem que trabalhar muito, e isso prejudica o professor. O salário do professor nós sabemos, faz parte sim do processo histórico de exclusão dos pobres, principalmente os negros, os afro descendentes, infelizmente é uma vergonha para o nosso pais, e enquanto a escola não enfrenta isso no ponto de vista de ver a escola como um ato político, a exclusão vai continuar até quando infelizmente eu acho que vai demorar, até que haja de fato educação de qualidade nesse pais. Infelizmente!
\end{abstract}

Para ele, bom mesmo seria incluir, mas pergunta: Como fazer isso? E acha que seria muito bom que nós pensássemos em políticas públicas, que fomentássemos isso denunciando as condições de trabalho e que nossos gestores pensassem novas propostas de implementar essas mudanças.

O professor $\mathrm{F}$ diz que, tanto nessa escola como na outra em que atua, em um bairro da região, percebe claramente como a exclusão social se reflete na escola, pois quanto pior é a vida do aluno, pior é o rendimento dele na escola. E que para serem incluídos, deveriam aceitar ajuda e eles não aceitam, diz ser difícil ajudar quem não quer ser ajudado.

O professor G diz que estudou pouco sobre inclusão para opinar sobre o assunto, mas, se a 
criança é pobre, mas tem um canto para ela ali colocar seus livros e sentar para estudar, mesmo que seja uma caixa de madeira, com certeza isso vai se refletir na escola. Mas existe a desestrutura da família, a criança chega em casa e não tem ninguém responsável por ela, que tome conta, não tem estímulo nem um cantinho para ela. Aí sim, ligaria ao fato da exclusão social estar ligada a dificuldades escolares. Acha que para incluir, enquanto professor ,não dá para fazer sozinho, a escola precisa diagnosticar, e informar aos professores sobre a situação e dificuldade do aluno, a ação precisa ser conjunta entre os profissionais da escola, e a base para isso é a reflexão, programar, fazer, pensar, experimentar, e se não der certo, refletir novamente sobre o que é preciso melhorar, mas sempre em ação conjunta.

O Professor $\mathrm{H}$ acredita que a desigualdade poderia ser sanada se a criança fosse melhor assistida desde a Educação Infantil. A realidade dos nossos alunos é muito difícil e tornar a escola um lugar agradável para eles é o nosso grande desafio, pois hoje, segundo ela, nosso sistema educacional está falido.

\footnotetext{
Nos computadores elas "viajam" muito e chegam na escola é aquela coisa tradicional ainda, você tem acesso a outras coisas, conhecimento não é só sala de aula. Eles já vem de uma realidade de exclusão e chegam na escola e não tem nada para atrair a atenção deles, a escola não tem nada de interessante para oferecer a eles, e nós na sala de aula não temos material físico, para ajudar.
}

A escola precisa trabalhar de forma a trazer o meio deles para a sala de aula, aproveitar a realidade deles e ensinar matemática, leitura, despertando seu interesse e a partir daí mostrar outras realidades, potencialidades.

Para a coordenadora, a dificuldade está ligada sim, pois percebe que muitos chegam a escola sem alimentação e muitos moram em espaços pequenos, sem divisão de cômodos, os pais saem para trabalhar muito cedo, e deixam os irmãos sozinhos, não dão suporte de acompanhamento das atividades escolares, não tem rotina de estudos nem um controle do horário em que a criança vai estudar. O menino fica solto e muitas vezes ao chegar no espaço escolar ele percebe regras e não foi acostumado a isso. Acaba virando um efeito dominó, a família não dá conta, e a escola também não dá.

Há uma necessidade dos pais de sair para trabalhar, em todas as classes sociais, mas algumas classes conseguem dar um suporte de cuidados aos filhos. Já nas família em que atendemos as crianças ficam soltas por aí, sem ter acompanhamento, aí chega na escola tem atividades, tem dever pois não tem um suporte em casa para dar conta dessas coisas.

Para resolver isso, primeiro devemos inserir eles dentro da escola como temos feito, porém temos que tentar ações e um suporte maior, pois o professor não dá conta de na sala de aula 
trabalhar todas as diferenças.

Muitos alunos chegam a $8^{a}$ série semialfabetizados, repensar o sistema também, não é somente um problema dentro da escola é um problema social nacional. Para que a inclusão aconteça dentro da sala de aula tem que ser trabalhados outros fatores, como comportamento, e trabalhar o aluno para que ele perceba algo que goste. O que ele gosta de fazer, o que prende a atenção deste menino e a partir daí começar a trabalhar outras coisas como, valores pessoais, autoestima, pois a deles é muito baixa. Primeiro porque não conseguem aprender, estão defasados idade/série e é constrangedor um menino de quinze anos estudar com um menino de dez, então seria ver outras formas de estar trabalhando com esses alunos. Como poderíamos fazer isso? Nós temos alunos na escola e percebemos esse tipo de realidade, mas ao acompanhar esses alunos e fazer uma avaliação para avançar, eles não tem domínio dos conteúdos necessários para o avanço, pois tem conteúdos que precisam ser cumpridos, cronogramas que são cobrados ao final de cada série. E se não temos condições de estar dando um suporte a esse aluno acabamos tendo problemas. É mais fácil encaminhar para outros órgãos e jogar a responsabilidade para fora da escola, a família joga pra escola e a escola joga para fora. E não temos o suporte que deveria como, ter uma equipe que pudesse estar trabalhando esse aluno no contra turno, ter condições de fazer com que esse aluno goste de estar na escola, pois essa criança não tem perspectiva nenhuma, o que que ele quer para vida dele, e eu falo isso porque quando a gente era criança a gente tinha, e eu não vejo, não percebo nas crianças discussões sobre isso. Para eles é muito mais fácil estar no mundo do crime, pois ele vai ter dinheiro fácil. A escola precisa melhorar para que possamos minimizar a exclusão social.

Ela diz também que essa questão, exclusão social e escola, é algo em que não podemos trabalhar sozinhos é preciso do apoio da saúde, o trabalho da gente depende de vários setores que vão interferir na vida escolar, se a família consegue ter condições dignas de atendimento hospitalar, moradia, condições de trabalho, facilitaria também o trabalho da escola com esses alunos.

É essa questão mesmo do capitalismo, a pirâmide financeira de que muitos têm pouco e poucos têm muito. Que vira uma bola de neve, que isso transfere para escola esses problemas, pois o menino tem uma vontade maior de ser traficante, isso torna-se muito mais vantajoso para ele que estar dentro da escola. Ele não precisa de dar conta de ler e escrever para ter o dinheiro dele e muitas vezes eles viram para você e falam que tem isso, tem aquilo então para que que eu vou estudar? A gente não vê como a escola vai consertar os problemas da sociedade. Não vemos algumas ações que deveriam ser feitas, como encaminhamento pra o conselho tutelar, e com a ação que deveria resolver o problema do menino, vai acabar surgindo outro problema, como o nome dele sujo. Isso vai gerar trabalho para a família. E a violência que surge dentro da escola é porque a gente não tem um suporte que nos ajude. Pois eles chegam na escola sem alimentação, sem roupa adequada, sem material, sem um monte de coisas que vão interferir na produção dele.

Todos os profissional entrevistados sabem que precisam incluir mas não sabem exatamente como, e assinalam a importância da formação em inclusão.

A maioria dos entrevistados tem um conceito de inclusão escolar que ressalta a importância do trabalho individualizado com a criança de acordo com suas necessidades. 
Os depoimentos dos professores e profissionais da escola me fez perceber que estamos obtendo avanços consideráveis no processo de inclusão dos alunos com dificuldades de aprendizagem e risco social, criando projetos para desenvolvimento de leitura e escrita. A Oficina de Leitura e Escrita acontece na escola desde 2010, com profissional contratado especificamente para isso e, nesse ano de 2011, com profissional efetivo. A oficina atende a alunos com dificuldades no turno e também do contra turno dependendo da demanda.

Para os professores com tempo livre de aula foram desenvolvidos projetos de Teatro que participarão os professores Arte e Língua portuguesa, começando com a leitura de um livro infanto juvenil de uma escritora jovem e que mora em um bairro próximo à escola, ela irá participar do projeto, indo até a escola conversar sobre o livro e sobre sua trajetória de escritora, membro da academia jovem de letras do Espírito Santo. A finalização do projeto é a montagem de uma peça tendo como base o livro.

Um projeto de desenvolvimento do raciocínio lógico, que envolve os professores de educação física e matemática, eles trabalharão também cinco tempos extras, com jogos que estimulem o raciocínio lógico dos alunos, priorizando o xadrez, visando melhorar o entendimento da matemática. 


\section{CONSIDERAÇÕES FINAIS}

Durante a pesquisa percebemos que os desafios de incluir os alunos são muitos, o principal é a falta de formação profissional. Os cursos de licenciatura não preparam o professor para lidar com uma escola diversa e inclusiva, mesmo o profissional que busca sua formação constante se depara com situações que não se sente preparado para lidar.

O maior desafio do professor, hoje, é a falta de uma formação que o prepare para lidar com essa situação que envolve tanto questões de exclusão social como de dificuldade de aprendizagem.

Determinadas escolas, inseridas dentro de uma região de periferia têm o problema social mais agravado, mas existem estudos que mapearam essas áreas mais complexas. Seria possível a secretaria de educação, proporcionar uma formação de professores e profissionais das escolas dessas regiões, de forma a lidar com essas questões que lhes são características. Redes de assistência social, de saúde que trabalhassem interligadas com a escola, de forma que os problemas diagnosticados fossem logo encaminhados e posteriormente resolvidos, ajudaria a minimizar o reflexo deles dentro da sala de aula. A escola não dá conta sozinha de tantas questões polêmicas que se interpõem com as questões escolares travando função principal que é o de passar conhecimento acadêmico.

No decorrer da pesquisa percebe-se que a escola estudada conseguiu avanços consideráveis desde o seu início no ano de 2006. A oficina de leitura e escrita, iniciada em 2009, hoje faz parte dos projetos da escola, foi uma grande conquista, percebe-se nos índices de reprovação, que caíram consideravelmente em 2010.

A oficina de matemática que é um projeto também de 2009, ainda não está funcionando pois depende de professor, mas já faz parte do plano de ação da escola.

No início do ano de 2011, outros dois projetos foram iniciados: O projeto de teatro que participam os professores de língua portuguesa e arte e o projeto de raciocínio lógico, que participam os professores de matemática e educação física.

Embora os projetos citados contribuam com o trabalho de inclusão social e escolar dos alunos, seria importante oferecer mais ferramentas profissionais para os professores da escola, por meio de uma formação continuada, voltada para a educação inclusiva, e, assim, possibilitar o 
desenvolvimento cognitivo, cultural e social desses alunos, respeitando suas diferenças e atendendo às suas necessidades, a escola precisa criar redes de apoio com outras instituições e setores importantes para a vida escolar do aluno, aproveitar a realidade e as motivações dos alunos no contexto do trabalho pedagógico, e refletir de forma crítica sobre as relações e interações que acontecem no cotidiano escolar e que podem se revelar como práticas inconscientes de exclusão. 


\section{REFERÊNCIAS}

ANGELUCCI, C. B. (2002) Uma inclusão nada especial, São Paulo: USP

ASSIS, S. G. de e CONSTANTINO, P. (2005) Perspectivas de prevenção da infração juvenil masculina, Ciênc. saúde coletiva vol.10 no.1 Rio de Janeiro

GLAT, R.; NOGUEIRA, M. L. L. (2002) Políticas Educacionais e a Formação de Professores para a Educação Inclusiva no Brasil. Revista Integração, Paraná

DESSEN, M.A.; POLONIA, A.C. (2007) A família e a escola como contextos de desenvolvimento humano, São Paulo: Paidéia

D'AVILA-BACARJI, K. M. G.; MARTURANO E. M.; ELIAS L. C. S. (2005) Recursos e adversidades no ambiente familiar de crianças com desempenho escolar pobre, Paidéia (Ribeirão Preto) vol.15 no.30 São Paulo

FEIJÓ, R. B.; OLIVEIRA E. A. (2001) Comportamento de risco na adolescência, Supl.2/S125, Jornal de Pediatria, Sociedade Brasileira de Pediatria

FERRÃO, M. E.; BELTRÃO, K. I.; SANTOS, D. P. (2002) O impacto de políticas de não repetência sobre o aprendizado dos aluno da $4^{\mathrm{a}}$ série, pesquisa e planejamento econômico. |

HÜNING, S. M. e GUARESCHI, N. M. de F. (2002) Tecnologias de governo: Constituindo a situação de risco social de crianças e adolescentes. PUC RS

MACEDO, C. S.; ANDREUCCI, L. C.; MONTELLI, T. C. B. (2004) Alterações cognitivas em escolares de classe sócio-econômica desfavorecida: resultados de intervenção psicopedagógica. Arquivos de Neuro-Psiquiatria. São Paulo.

MANTOAN, M. T. E.; PRIETO R. G.; ARANTES V. A. (org.) (2006) Inclusão Escolar: 
pontos e contrapontos. Summus Editorial, São Paulo.

MATTOS, C. L. G. (2005) O conselho de classe e a construção do fracasso escolar, Educação e Pesquisa, São Paulo.

MARTINEZ, A. M. em TACCA , Mª C. V. R. (2006) Aprendizagem e trabalho pedagógico, Alínea ED, São Paulo.

READ, H. A educação pela arte. Tradução de Valter Lellis Siqueira. (2001) Martins Fontes, São Paulo.

TUNES, E.; TACCA M.C.V.R.; BARTHOLO JÚNIOR, R.S. (2005) $\underline{\mathrm{O} \text { professor e o ato de }}$ ensinar, São Paulo: Cadernos de Pesquisa.

XAVIER, M. L. (org.) (2002) Disciplina na escola: enfrentamentos e reflexões, Editora Mediação, Porto Alegre. 


\section{APÊNCICES}

\section{A - Roteiro de entrevistas}

Formação:

Ano que formou:

Qual foi sua última atualização?

Em suas turmas tem aluno com dificuldade de aprendizagem?

O que é feito para que esses alunos consigam avançar?

Como é o comportamento dos alunos com dificuldades de aprendizagem?

O que você faz com alunos que não fazem atividades em sala de aula?

Você poderia definir inclusão escolar?

Você tem alguma formação em inclusão escolar?

Quais os desafios que a inclusão traz ao seu trabalho? Você poderia dar alguns exemplos?

Você acha que a dificuldade de aprendizagem está ligada a uma história de exclusão social? Por quê? Como?

Como você acha que deveria acontecer a inclusão dos alunos com dificuldades de aprendizagem e com um histórico de exclusão social? Por quê? Você poderia dar exemplos concretos a partir de sua experiência? Quais?

Essas foram as últimas perguntas, você gostaria de acrescentar alguma coisa ou falar de alguma questão que não foi abordada? 


\section{TERMO DE CONSENTIMENTO LIVRE E ESCLARECIDO}

\section{Entrevista individual - Profissionais}

Senhor(a) professor(a):

Convido o(a) senhor(a) para participar de uma entrevista individual, que fará parte de uma pesquisa sobre Inclusão Escolar de Alunos em Situação de Risco Social: Desafios e Possibilidades no contexto escolar, pela qual sou responsável. Esclareço que a sua participação na entrevista é voluntária, sendo que você está livre para participar ou não da mesma, e que você poderá deixar a pesquisa a qualquer momento que desejar. Caso você aceite o convite, gostaria de sua autorização para que a entrevista seja gravada em áudio, com o intuito de facilitar a análise da mesma. Esclareço, também, que você está livre para aceitar ou não a gravação da entrevista em áudio.

Sou aluna do Curso de Especialização em Desenvolvimento Humano, Educação e Inclusão Escolar, da UAB/UnB, e estou realizando um estudo sobre alunos em risco social e sua inclusão no processo de aquisição de conhecimento, no contexto escolar. Este estudo não tem risco para seus participantes, e beneficiará crianças, pais e professores, pois ele visa fornecer informações para melhorar a qualidade da prática pedagógica dos professores e das instituições de ensino e, assim, melhorar o atendimento oferecido às crianças e pais, na escola.

Para a realização do estudo será necessário realizar uma entrevista individual com os profissionais da escola, conforme a disponibilidade dos mesmos. Também será necessário gravar em áudio a entrevista. Este registro será para uso exclusivo da pesquisa, e não será divulgado, através de qualquer meio, em nenhuma hipótese. O participante da entrevista será, desde o inicio, identificado através de nome fictício que irá preservar sua identidade. Enfatizo que a identidade do entrevistado, e da própria escola, será mantida em total sigilo, em qualquer circunstância

Como colocado anteriormente, a participação na entrevista é voluntária e as respostas livres de qualquer obrigação ou dever. Informo também, que a entrevista terá no máximo uma hora de duração. Os dados obtidos, a partir da análise da entrevista, serão utilizados apenas e tão somente para os objetivos da pesquisa.

Caso tenha alguma dúvida sobre o estudo, o(a) senhor(a) poderá me contatar pelo telefone 99834204 ou no endereço eletrônico cass.guid@ hotmail.comcass.guid@hotmail.com.

Desde já, agradeço antecipadamente sua atenção e colaboração.

Cordialmente,

\section{Cassia Guidoni}

Curso de Especialização em Desenvolvimento Humano, Educação e Inclusão Escolar Universidade Aberta do Brasil-UnB

Sim, concordo em participar da entrevista e com a gravação em áudio da mesma.

Nome:

Assinatura:

E-mail (opcional): 


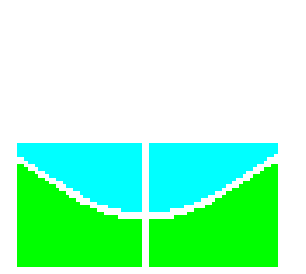

Universidade de Brasília - UnB

Instituto de Psicologia - IP

Departamento de Psicologia Escolar e do Desenvolvimento - PED

Programa de Pós-graduação em Processos de Desenvolvimento Humano e Saúde PGPDS

\section{ANEXOS}

A(o) Diretor(a)

Escola....

De: Profa. Dra. Diva Albuquerque Maciel

Coordenadora Geral do Curso de Especialização em Desenvolvimento Humano, Educação e Inclusão Escolar

\section{Assunto: Coleta de Dados para Monografia}

Senhor (a), Diretor (a),

A Universidade Aberta do Brasil - Universidade de Brasília está em processo de realização da $1^{a}$ oferta do curso de Especialização em Desenvolvimento Humano, Educação e Inclusão Escolar, do qual seis dentre as 20 turmas ofertadas são de professores e educadores da rede pública do DF (polos UAB-UnB de Santa Maria e Ceilandia). Finalizamos agora a $1^{\mathrm{a}}$ fase do curso e estamos iniciando a Orientação de Monografia.

È requisito parcial para a conclusão do curso, a realização de um um estudo empírico sobre tema acerca da inclusão no contexto escolar, cujas estratégias metodológicas podem envolver: entrevista com colegas, pais ou outros participantes; observação; e análise documental.

A realização desses trabalhos tem como objetivo a formação continuada dos professores/servidores da rede pública, subsidiando-os no desenvolvimento de uma prática pedagógica refletida e transformadora, tendo como consequência uma educação inclusiva.

Informo que foi autorizado pela Secretaria de Educação por meio do ofício n⿳亠

DEM datado de 28/10/2010, a realização das coletas de dados para as pesquisas na Rede Pública de Ensino do Distrito Federal.

Informações a respeito dessa autorização podem ser verificadas junto a Secretaria de Educação por meio dos telefones $n^{\circ}$.

O trabalho será realizado pelo Professor/cursista sob orientação cujo tema é:

possa ser desenvolvido na escola sob sua direção.

Desde já agradeço, colocando-me a disposição de Vossa Senhoria para maiores esclarecimentos nos telefones. (061) ou por meio dos e-mails:.

Atenciosamente,

\section{Diva Albuquerque Maciel}

Coordenadora Geral do Curso de Especialização em Desenvolvimento Humano, Educação e Inclusão Escolar 